\title{
Effect of Steroid Therapy on Thyroid Function Status in Typically and Atypically Presented Nephrotic Syndrome
}

\author{
Mitra Datta ${ }^{1 *}$ \\ Mohammed Maruf-ul-Quader ${ }^{2}$ \\ Salina Haque ${ }^{3}$ \\ Sumana Choudhury ${ }^{4}$ \\ Shuvra Das ${ }^{5}$ \\ Taniina $\mathrm{Hoq}^{6}$ \\ Pranab Kumar Chowdhury ${ }^{7}$
}

'Department of Pediatrics Chattogram Medical College Chattogram, Bangladesh.

${ }^{2}$ Department of Pediatric Nephrology Chattogram Medical College Chattogram, Bangladesh.

${ }^{*}$ Correspondence to:

\section{Dr. Mitra Datto}

Junior Consultant

Department of Pediatrics

Chattogram Medical College

Chattogram. Bangladesh.

Mobile : +88 01812510063

Email:mitradatta71@gmail.com

Date of Submission : 09.10 .2019

Date of Acceptance : $\quad 15.11 .2019$

www.banglajol.info/index.php/CMOSHMCJ

\begin{abstract}
Background: Mild or subclinical hypothyroidism may coexist with Nephrotic Syndrome (NS). But persistence of this hypothyroidism is related with remission of proteinuria. Objectives of the study is to compare thyroid function status (FT and TSH) in the atypical and typical NS before and 4 weeks after steroid therapy.
\end{abstract}

Materials and methods: This was a hospital based comparative observational study with prospective follow up of study subjects. It was carried out in the Department of Pediatrics and in the Department of Nephrology, Chattogram Medical College Hospital (CMCH) Chattogram, Bangladesh from January to December' 2017. A total 83 diagnosed admitted cases of initial attack idiopathic NS, aged 1-18 years of either sex divided into 2 groups were included. Typically presented NS were in group $A$ and atypically presented NS were in group B. FT and TSH were estimated in all patients on 2 occasions before and 4 weeks after initiation of steroid therapy and comparison was done between 2 groups.

Results: $\mathrm{FT}_{4}$ level was normal before and after steroid therapy in both typically and atypically presented nephrotic syndrome. Before steroid therapy, mean TSH value was found significantly raised in both groups $(9.28 \pm 5.17$ vs $7.26 \pm 3.67 \mu / \mathrm{U} / \mathrm{ml})$. Proportion of subclinical hypothyroidism was statistically similar. After treatment with steroid, number of subclinical hypothyroid cases reduced in both groups with reduction of TSH value (3.13 \pm 1.14 vs $5.38 \pm 2.52 \mu \mathrm{IU} / \mathrm{ml})$. But significant difference in TSH value was observed in between two groups. There was persistence of subclinical hypothyroidism after treatment with steroid among $16.6 \%$ (14.2\% grade II and $2.3 \%$ grade I) children with atypically presented NS and which is statistically significant ( $p=0.006)$.

Conclusion: Subclinical hypothyroidism persists in atypically presented nephrotic syndrome even after treatment with steroid.

Key words: Typically presented nephrotic syndrome; Atypically presented nephrotic syndrome; Thyroid function status; Steroid therapy.

\section{INTRODUCTION}

Kidney and thyroid function and dysfunction are interrelated through several mechanisms ${ }^{1}$. Proteinuria in Nephrotic Syndrome (NS) often results in urinary losses of thyroid hormones bound to the various binding proteins such as Thyroxine Binding Globulin (TBG) transthyretin (Pre albumin) and albumin ${ }^{2}$. These urinary losses of thyroid hormones increase TSH concentrations by triggering stimulation of hypothalamus-pituitary-thyroid axis. If thyroid gland able to compensate the hormone losses, patient can remain euthyroid. Otherwise, patients present with various kinds of thyroid function abnormality ${ }^{3}$. Subclinical hypothyroidism is more frequent in patient with Nephrotic Syndrome (NS) ${ }^{4}$. But this is reversible on remission ${ }^{5}$. However, in patients with low thyroid reserve overt hypothyroidism 
may develop. Thyroid hormone changes are related both to the severity of proteinuria and the level of serum albumin in patients with Idiopathic Nephrotic Syndrome (INS) ${ }^{2,3}$.

Glucocorticoids commonly used to treat patients with proteinuria, directly affect the thyroid function ${ }^{6}$. Glucocorticoids decrease TRH messenger RNA levels in the hypothalamus leading to lower TSH secretion ${ }^{7}$. In patients with hypothyroidism the receptor of glucocorticoid is reduced. So effect of steroid on kidney is decreased ${ }^{8}$. Combined treatment with low-dose levothyroxine supplementation and steroids in children with INS complicated by thyroid dysfunction may reduce proteinuria compared with treatment with steroid only ${ }^{3}$. Sharma $\mathrm{S}$ et al and Kapoor $\mathrm{K}$ et al observed that prolonged proteinuria and glucocorticoids used to treat the patient affect the thyroid function in Steroid Resistant Nephrotic Syndrome (SRNS), ${ }^{9}$. Kenichi Kano et al also reported that thyroid replacement therapy in a nephrotic boy with hypothyroidism and glucocorticoid resistance resulted in early steroid response and prompt disappearance of proteinuria in addition to normalization of thyroid function ${ }^{11}$. Normalizing $T_{3}$ and $T_{4}$ concentrations with replacement therapy preserves renal function in these patients and is a predictor of renal outcome ${ }^{12}$.

The presence of atypical features such as gross hematuria, hypertension, low $\mathrm{C}_{3}$ level and impaired renal function indicate the patients who are likely to have other than Minimal Change Nephrotic Syndrome (MCNS) and steroid resistance ${ }^{13}$. So subclinical or overt hypothyroidism may present in atypically presented NS even after steroid therapy. Aim of this study to find whether hypothyroidism is persistent 4 weeks after steroid therapy in typically or atypically presented NS. If nephrotic syndrome is accompanied by hypothyroidism, this may affect water- electrolyte hemostasis and may exacerbate fluid retention, which may be difficult to resolve if the treatment of hypothyroidism is delayed. These patients have worse quality of life and poor prognosis ${ }^{14}$.

This study may guide whether atypically presented NS children need thyroid replacement therapy or not. So no hypothyroid will left untreated from the very beginning.

\section{MATERIALS AND METHODS}

This hospital based comparative observational study with prospective follow up of study subjects was carried out in the Department of Pediatrics and Nephrology, $\mathrm{CMCH}$, Chattogram, from January' 2017 to December 2017. A total 83 cases of initial attack idiopathic nephrotic syndrome, aged 1-18 years of either sex divided into 2 groups was included in this study. Group A included 41 nephrotic children with typical presentations (No hematuria, no hypertension, normal $\mathrm{C}_{3}$ level and normal renal function) and group $\mathrm{B}$ included $42 \mathrm{NS}$ patients with atypical presentations (Hematuria, hypertension, low $\mathrm{C}_{3}$ level, and impaired renal function). Children with Secondary nephrotic syndrome (Infection-HBV, systemic illness-SLE, HSP) known thyroid disease (Hypo/ hyperthyroidism before the onset of nephrotic syndrome) hematuria due to urinary tract infection, hypertension and edema due to other causes, nephrotic syndrome $<1$ year or $>18$ years was excluded. Thyroid hormone ( $\mathrm{FT}_{4}$ and $\mathrm{TSH}$ ) was estimated in all patients on 2 occasions before and 4 weeks after initiation of steroid therapy.

Subclinical Hypothyroidism: Subclinical hypothyroidism is defined as an elevation in serum TSH above the upper limit of the reference range with a normal serum $\mathrm{FT}_{4}$ concentration. Classified as follows :-

Grade I : Subclinical hypothyroidism was defined as TSH greater than $4.5 \mu \mathrm{IU} / \mathrm{L}$ and $<6 \mu \mathrm{IU} / \mathrm{L}$

Grade II : TSH between 6-12

Grade III : TSH $>12 \mu \mathrm{IU} / \mathrm{L}$, with normal $\mathrm{FT}_{4}$ concentration.

Overt Hypothyroidism: Overt Hypothyroidism is defined as the low $\mathrm{FT}_{4}$ (Normal: $0.7-2.00 \mathrm{ng} / \mathrm{dl}$ or $9.0-25.7 \mathrm{nmol} / \mathrm{L}$ ) and elevated serum TSH above the upper limit of reference range $(>4.5 \mu \mathrm{IU} / \mathrm{L})^{15}$.

Euthyroid: Euthyroid is defined as the state of having normal thyroid gland function ${ }^{15}$.

Steroid Resistance: Steroid resistance was defined as failure to achieve remission despite $2 \mathrm{mg} / \mathrm{kg} /$ day of daily prednisolone for 4 weeks ${ }^{16}$.

Typically Presented Nephrotic Syndrome: Typically presented nephrotic syndrome represents children with nephrotic syndrome presented with no hematuria, normal blood pressure, normal serum complement level, normal renal function and steroid responsiveness ${ }^{17}$.

Atypically Presented Nephrotic Syndrome: Atypically presented nephrotic syndrome represents children with nephrotic syndrome presented with higher age of onset, hematuria, hypertension, impaired renal function, hypocomplementaemia and above all steroid resistance ${ }^{18}$.

Hematuria: Hematuria is considered both microscopic (Presence of more than $5 \mathrm{RBCs} /$ high power field on a centrifuged urine specimen) and macroscopic hematuria.

Hypertension: Hypertension is considered as systolic and/or diastolic blood pressure that is $\geq 95^{\text {th }}$ percentile for the age, sex and height on $\geq 3$ occasions or BP above 120/80 mm of Hg.

Impaired Renal Function: Impaired renal function is defined as elevation in serum creatinine level beyond the normal range for the patient's age.

Hypo-complementaemia is considered as serum $\mathrm{C}_{3}$ level less than $0.9 \mathrm{~g} / \mathrm{L}$ and serum $\mathrm{C}_{4}$ level less than $0.1 \mathrm{~g} / \mathrm{L}$.

Each participant was subjected to thorough history and clinical assessment including age of onset of disease, family history, measurement of blood pressure, findings of bedside urine examination. Initially 96 children with heat coagulation test urinary protein $>2+$ was included. Investigations necessary for diagnosis of NS were done. Other investigations were as follows- urine for routine and microscopic examination, culture 
with colony count and sensitivity test, complete blood count, serum creatinine, serum $\mathrm{C}_{3}$ and $\mathrm{C}_{4}$ level, serum electrolyte, ANA, Antids DNA, HBsAg, Mantoux test, chest X-ray and Ultrasonography of kidney urinary bladder region. Nephrotic syndrome was confirmed by urinary protein excretion $>1 \mathrm{gm} / \mathrm{m} 2 /$ day or spot urine protein: creatinine ratio $>2$, serum albumin $<2.5 \mathrm{gm} / \mathrm{dl}$, high serum cholesterol $>200 \mathrm{mg}$ dl. There was indication of renal biopsy for every child with atypically presented nephrotic syndrome. But in this study renal biopsy was performed in 12 cases. Then patients were divided into 2 groups according to clinical and biochemical criteria. Fasting serum FT4 and TSH level was estimated in every study subject before receiving treatment with prednisolone according to standard protocol. Antihypertensive drugs were added to control hypertension in hypertensive children. Immunosuppressive drugs were added later on to treat some of the children with atypically presented NS. But during study period they were receiving prednisolone while waiting for biopsy report to start alternative treatment. After completion of 4 weeks treatment with prednisolone, out of 41 typically presented NS patient 39 patients were in complete remission and rest 2 patients who were suffering from infection were not in remission but, achieved remission after infection. Among 42 patients of atypically presented NS 28 patients were in complete remission and 14 patients were not in remission. Serum $\mathrm{T}_{4}$ and $\mathrm{TSH}$ were estimated again in all patients. No patient was given Thyroxin. Serum $\mathrm{TSH}$, serum $\mathrm{FT}_{4}$ and serum $\mathrm{FT}_{3}$ were estimated by Automated Chemiluminescent Immunoassay system by Beckman Coulter, Access-2 (Normal value for TSH0.4-4.5 $\mu \mathrm{IU} / \mathrm{ml}$, FT4-0.7-2.00ng/dl). Data were analyzed using SPSS version 23. Independent (Unpaired) and paired Student's t-test was used to compare continuous variables. Paired categorical data were compared using McNemar test and unpaired categorical data by $\chi^{2}$ test.

\section{RESULTS}

Age distribution showed mean age was significantly higher in Group B $(10.01 \pm 1.82)$ than Group A $(4.33 \pm 1.63)$ years (Table I). Steroid response after 4 weeks in group A was $95 \%$ and in group B was 67\% (Figure 1).

Before steroid therapy, mean serum TSH level raised in both Groups $(9.28 \pm 5.17$ vs $7.26 \pm 3.67) \mu \mathrm{IU} / \mathrm{ml}$. After steroid this valuereturned to normal level in group Abut remained persistently raised $(3.13 \pm 1.14$ vs $5.38 \pm 2.52 \mu \mathrm{IU} / \mathrm{ml})$ in group B with significant difference in $(\mathrm{p}=0.047)$. Serum $\mathrm{FT}_{4}$ level was within normal range before and 4 weeks after steroid therapy in both group A and group B (Table II). Reduction of TSH value was more significant in group $A(p=0.001)$ than group $B$ $(\mathrm{p}=0.048)$ (Table III).

In group A 18 nephrotic children were hypothyroid before steroid therapy and all of them became euthyroid after steroid therapy (Table IVa) whereasin group B among 16 nephrotic children who were hypothyroid before steroid therapy, 7 children remained persistently hypothyroid after steroid treatment (Table $I V b)$. But in both groups significant difference $(p<0.05)$ present in thyroid function status before andafter steroid therapy (Table IVa \& IVb). Proportion of subclinical hypothyroidism were similar in two groups before steroid therapy but after steroid therapy proportion was $16.6 \%$ in group B which was significantly higher than Group A (Table V).

Table I: Age distribution of the study population by Groups

\begin{tabular}{lrrrrrr} 
Age, in years & \multicolumn{2}{c}{ Group A } & \multicolumn{2}{c}{ Group B } & \multicolumn{2}{c}{ Total } \\
& $\mathbf{n}$ & $\%$ & $\mathbf{n}$ & $\%$ & n & $\%$ \\
Category & & & & & & \\
$<2$ & 2 & 4.9 & 0 & 0.0 & 2 & 2.4 \\
$2-8$ & 38 & 92.7 & 2 & 4.8 & 40 & 48.2 \\
$>8$ & 1 & 2.4 & 40 & 95.2 & 41 & 49.4 \\
Total & 41 & 100.0 & 42 & 100.0 & 83 & 100.0 \\
Mean \pm SD & $4.33 \pm 1.63$ & $10.01 \pm 1.82$ & \multicolumn{2}{c}{ p value=0.001* } \\
\hline
\end{tabular}

*Significant by Independent sample $t$ test

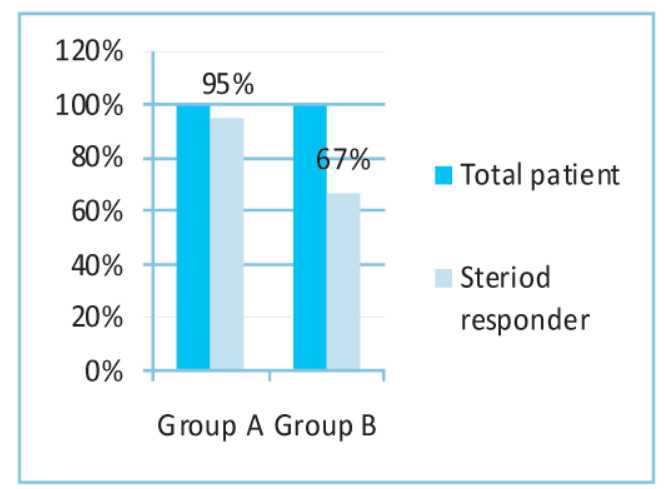

Figure 1: Bar chart showing steroid response in Group A \& Group B

Table II: Comparison of TSH and $\mathrm{FT}_{4}$ values between two Groups

\begin{tabular}{llll} 
Time and parameters & $\begin{array}{l}\text { Group A } \\
(\mathrm{n}=\mathbf{4 1}) \\
\text { Mean } \pm \text { SD }\end{array}$ & $\begin{array}{l}\text { Group B } \\
(\mathrm{n}=42) \\
\text { Mean } \pm \text { SD }\end{array}$ & p value \\
$\begin{array}{l}\text { Before therapy } \\
\mathrm{TSH}(\mu \mathrm{IU} / \mathrm{ml})\end{array}$ & $9.28 \pm 5.17$ & $7.26 \pm 3.67$ & 0.56 \\
$\mathrm{FT}_{4}(\mathrm{ng} / \mathrm{dl})$ & $1.03 \pm 0.31$ & $1.07 \pm 0.23$ & 0.52 \\
After therapy $_{\mathrm{TSH}(\mu \mathrm{IU} / \mathrm{ml})}$ & $3.13 \pm 1.14$ & $5.38 \pm 2.52$ & $0.047^{*}$ \\
$\mathrm{FT}_{4}(\mathrm{ng} / \mathrm{dl})$ & $1.22 \pm 0.33$ & $1.29 \pm 0.31$ & 0.34 \\
*Significant by Independent sample t test & & \\
\hline
\end{tabular}

Table III : Comparison of TSH and $\mathrm{FT}_{4}$ values before and after steroid therapy

\begin{tabular}{llll}
$\begin{array}{l}\text { Groups and } \\
\text { Parameters }\end{array}$ & $\begin{array}{l}\text { Before therapy } \\
\text { Mean } \pm \text { SD }\end{array}$ & $\begin{array}{l}\text { After therapy } \\
\text { Mean } \pm \text { SD }\end{array}$ & p value \\
$\begin{array}{l}\text { Group A }(\mathbf{n}=41) \\
\text { TSH }(\mu \mathrm{IU} / \mathrm{ml})\end{array}$ & $9.28 \pm 5.17$ & $3.13 \pm 1.14$ & $<0.001^{*}$ \\
FT4 $(\mathrm{pg} / \mathrm{ml})$ & $1.03 \pm 0.31$ & $1.22 \pm 0.33$ & 0.065 \\
Group B $(\mathrm{n}=42)$ & & & \\
TSH $(\mu \mathrm{IU} / \mathrm{ml})$ & $7.26 \pm 3.67$ & $5.38 \pm 2.52$ & $0.048^{*}$ \\
FT4 $(\mathrm{pg} / \mathrm{ml})$ & $1.07 \pm 0.23$ & $1.29 \pm 0.31$ & 0.068 \\
TSH $(\mu \mathrm{IU} / \mathrm{ml})$ & $9.28 \pm 5.17$ & $3.13 \pm 1.14$ & $<0.001^{*}$ \\
\hline
\end{tabular}

*Significant by paired sample $t$ test 
Table IVa: Thyroid status in Group A ( $\mathrm{n}=41)$ before and after steroid

\begin{tabular}{|c|c|c|c|c|}
\hline & Thyroid Status & \multicolumn{2}{|c|}{ After Therapy } & Total \\
\hline \multicolumn{5}{|l|}{ Before } \\
\hline \multirow[t]{5}{*}{ Therapy } & & Euthyroid & Hypothyroid & \\
\hline & & $\mathrm{n}$ & $\mathrm{n}$ & \\
\hline & Euthyroid & 23 & 0 & 23 \\
\hline & Hypothyroid & 18 & 0 & 18 \\
\hline & Total & 41 & 0 & 41 \\
\hline
\end{tabular}

Significant difference $(\mathrm{p}<0.05)$ by Mc Nemar test

Table IVb: Thyroid status in Group B ( $\mathrm{n}=42)$ before and after steroid

\begin{tabular}{|c|c|c|c|c|}
\hline & Thyroid Statu & \multicolumn{2}{|c|}{ After Therapy } & Total \\
\hline \multicolumn{5}{|l|}{ Before } \\
\hline Therapy & & Euthyroid & Hypothyroid & $\mathrm{n}$ \\
\hline & Euthyroid & 26 & 0 & 26 \\
\hline & Hypothyroid & 9 & 7 & 16 \\
\hline & Total & 35 & 7 & 42 \\
\hline
\end{tabular}

Significant difference $(\mathrm{p}<0.05)$ by Mc Nemar test

Table V : Comparison of Thyroid status in two groups

\begin{tabular}{|c|c|c|c|c|c|}
\hline \multirow[t]{2}{*}{$\begin{array}{l}\text { Time and } \\
\text { thyroid status }\end{array}$} & \multicolumn{2}{|c|}{$\begin{array}{c}\text { Group A } \\
(\mathrm{n}=41)\end{array}$} & \multicolumn{2}{|c|}{$\begin{array}{c}\text { Group B } \\
(n=42)\end{array}$} & \multirow[t]{2}{*}{$p$ value } \\
\hline & $\mathrm{n}$ & $\%$ & $\mathrm{n}$ & $\%$ & \\
\hline \multicolumn{6}{|l|}{ Before therapy } \\
\hline Euthyroid & 23 & 56.1 & 26 & 61.9 & 0.561 \\
\hline Hypothyroid & 18 & 43.9 & 16 & 38.1 & \\
\hline \multicolumn{6}{|l|}{ After therapy } \\
\hline Euthyroid & 41 & 100.0 & 35 & 83.3 & $0.006^{*}$ \\
\hline Hypothyroid & 0 & 0.0 & 7 & 16.6 & \\
\hline
\end{tabular}

*Significant by Chi-square test

\section{DISCUSSION}

In this study, high TSH level became normal 4 weeks after steroid therapy in typically presented NS children which is consistent with the findings of Afroz S et al and Sahni V et al 19,20 . But persistently higher TSH was observed in atypically presented NS children which was similar to the findings of Dagan A et al and Marimuthu $\mathrm{V}$ et al in SRNS children ${ }^{21,22}$. TSH value was $6.92 \pm 2.9 \mu \mathrm{IU} / \mathrm{ml}$ and $4.55 \pm 4.64 \mu \mathrm{IU} / \mathrm{ml}$ respectively. Increased serum TSH value in the study children may be attributed to negative feedback due to marked urinary loss of TBG and thyroid hormone bound to them.

Serum $\mathrm{FT}_{4}$ level was normal in all children before and after steroid therapy. This result is in agreement with result observed by Afroz $\mathrm{S}$ et $\mathrm{al}^{19}$. However, low serum $\mathrm{FT}_{4}$ levels have been reported in NS children by Hajizadeh $\mathrm{N}$ et al and Ito $\mathrm{S}$ et $\mathrm{al}^{23,24}$. Overt hypothyroidism may develop in SRNS according to Sharma $\mathrm{S}$ et al and Dagan A et al and Marimuthu $\mathrm{V}$ et al $\mathrm{l}^{9,21,22}$.
This study also showed $43.9 \%$ of typically presented NS children and $38.1 \%$ of atypically presented NS children developed subclinical hypothyroidism before steroid therapy. Higher incidence of hypothyroidism was observed by Choudhury $\mathrm{J}$ et al and Hajizadeh $\mathrm{N}$ et al which were $50 \%$ and $58.6 \%$ respectively ${ }^{25,23}$. But their observations were on children with NS irrespective of typical or atypical presentation.

In this study persistent subclinical hypothyroidism 4 weeks after steroid therapy was observed among $16.6 \%$ (4 were grade II and 3 were grade I) of atypically presented NS children. Sharma $\mathrm{S}$ et al, Kapoor $\mathrm{K}$ et al and Marimuthu $\mathrm{V}$ et al also observed subclinical hypothyroidism in SRNS children and the prevalence was $20 \%, 30 \%$ and $33.3 \%$ respectively ${ }^{9,10,22}$. But in this study only 14 atypically presented NS patients were steroid resistant. Among the atypically presented NS children with subclinical hypothyroidism 5 cases were steroid resistant. All the hypothyroid cases were subclinical hypothyroidism. Kano $\mathrm{K}$ et al showed nephrotic children develop mild hypothyroidism in active, untreated phase and also in high dose prednisolone treatment phase despite remission of proteinuria ${ }^{26}$. Kapoor K et al also observed subclinical hypothyroidism in SRNS though half was in partial and half in complete remission ${ }^{9}$. But Afroz S et al and Sahni $\mathrm{V}$ et al observed mild or subclinical hypothyroidism which develops in NS during proteinuria improves on remission ${ }^{19,20}$.

\section{LIMITATION}

Although this study has some limitation like- single centre study, small sample size, short duration, absence of further follow up, renal biopsy was not possible to be done in all the atypically presented NS patients so histopathological correlation with the thyroid function was not done, yet this can be mentioned that, in typically presented NS children thyroid function improves on remission.

\section{CONCLUSION}

Earlier remission of proteinuria may lead to significant improvement of thyroid function status. But persistent subclinical hypothyroidism present in atypically presented NS children even 4 weeks after steroid therapy. This may due to combined effect of high dose of steroid and prolong proteinuria. Subclinical hypothyroidism is present in both typically and atypically presented nephrotic syndrome before steroid therapy. But subclinical hypothyroidism persists even after steroid therapy in atypically presented nephrotic syndrome.

\section{RECOMMENDATION}

Further study to evaluate thyroid function status in children with atypically presented nephrotic syndrome even after steroid therapy to get the actual idea about the incidence of persistent subclinical hypothyroidism as well as study on effect of thyroid supplement on remission.

\section{DISCLOSURE}

All the authors declared no competing interest. 
1. Iglesias P, Bajo MA, Selgas R, Diez JJ Thyroid dysfunction and kidney disease: Anupdate. RevEndocrMetabDisord. 2017;18(1):131-144 Doi: 10.1007/s11154-016-9395-7.

2. Feinstein El, Keptein EM, Nicoloff JT. Thyroid function in patients with nephrotic syndrome and normal renal function. Amirican journal of nephrology. 1982;2:70-76.

3. Guo QY, Zhu QJ, Liu YF, Zhang HJ, Ding Y, Zhai WS et al. Steroid combined with levothyroxine to treat children with idiopathic nephrotic syndrome: A retrospective single-center study. PediatrNephrol. 2014;29:1033-1038.

4. Gilles, M. den Heijer, A. H. Ross, F. C. G. J. Sweep, A. R. M. M. Hermus and J. F. M. Wetzels. Thyroid function in patients with proteinuria. Netherlands Journal of Medicine. 2008;66(11):483-485.

5. Sawant SU, Chandran S, Almeida AF, Rajan MGR. Correlation between Oxidative Stress and Thyroid Function in Patients with Nephrotic Syndrome. Int.J.Nephrol. 2011;256420.

6. Haugen BR. Drug that suppress TSH or cause central hypothyroidism. Best Pract res ClinEndocrinolMetab. 2009;23(6):793-800.

7. Alkemade A, Unmehopa UA, Wiersinga WM, Swaab DF, Fliers E et al. Glucocorticoids decrease thyrotroin-releaseing hormone messenger ribonucle acid expression in the paraventricular nucleus of the human hypothalamus. J ClinEndocrinolMetab. 2005;90(1):323-327.

8. Ito S, Kano K, Ando T, Ichimura T. Thyroid function in children with nephrotic syndrome. Pediatric Nephrol. 1994;8(4):412-415.

9. Sharma S, Dabla PK, Kumar M. Evaluation of thyroid hormone status in children with steroid resistant nephrotic syndrome: A North India Study. EndocrMetab immune Disord Drug Tergets. 2015;15(4);321-324.

10. Kapoor K, Saha A, Dubey NK, Goyal P, Suresh CP, Batra V. Subclinical non autoimmune hypothyroidism in children with steroid resistant nephritic syndrome. ClinExpNephrol. 2014;18(1):113-117.

11. Kano K, Hagane M, Ito S, Ichimura T. Thyroid therapy for a boy with nephrotic syndrome. J JpnPediatr Soc. 1993;97:1298.

12. Shin DH, Lee MJ, Swung JK. Preservation of renal function by thyrpid hormone replacement therapy in chronic kidney disease patients with subclinical hypothyroidism. J cli endocrinol metab.2012;97:2732-2740.

13. Kumar J, Gulati S, Sharma A. P, Sharma R. K, Gupta R. K. Histopathological spectrum of childhood nephrotic syndrome in Indian children. PediatrNephro. 2003;18:657-660

14. Mario FD, Pofi R et al. Hypothyroidism and Nephrotic Syndrome: Why, When and How to treat. J Current VasculalPharmacoly. 2017;15(5):398-403.

15. Nananda FC, Martin IS, Gilbert HD. Subclinical thyroid disease; clinical applications. JAMA. 2004;291:239-243.

16. Niaudet P, Boyer O. Idiopathic Nephrotic Syndrome in Children: Clinical Aspects. In: Avner ED, Harmon WE, Niaudet P, Yoshikawa N, Emma F, Goldstein SL, editor. Pediatric Nephrology. $7^{\text {th }}$ edition. Heidelberg: Springer. 2016;840-869.

17. Bagga A, Srivastava RN. Nephrotic syndrome. In: Srivastava RN, Bagga A, editors.Pediatric Nephrology. $6^{\text {th }}$ edition. New Delhi: Jaypee Brothers Medical Publishers. 2016;195-234.

18. ISKDC. Primary Nephrotic syndrome in children: Clinical significance of Histopathologic variants of minimal change and diffuse mesangial hypercellularity. Kidney international. 1982;20:765-771.

19. Afroz S, Khan AH, Roy DK. Thyroid function in children with nephrotic syndrome. Mymensingh Med J. 2011;20(3):407-411.

20. Sahni V, Nanda S. Hypothyroidism in nephrotic syndrome in children. IOSR. 2014;13(8):07-11.

21. Dagan A, Cleper R, Krause I, Blumenthal D, Davidovits M. Hypothyroidism in children with steroid-resistant nephrotic syndrome. Nephrol Dial Transplant. 2012;27(6):2171-2175

22. Marimuthu V, Krishnamurthy S, Rajappa M.Non-Autoimmune Subclinical and Overt Hypothyroidism in idiopathic Steroid-resistant Nephrotic Syndrome in children. Indian Pediatr. 2017;54(11):925-929.

23. Hajizadeh N, Sayed M, Behnam N Niloofar H, Sayed M, Behnam N. Examine of thyroid function in pediatric nephrotic syndrome. Intern J Pediatr. 2015;3(2):59-65.

24. Ito S, Kano K, Ando T, Ichimura T. Thyroid function in children with nephrotic syndrome. Pediatric Nephrol. 1994; 8(4):412-415.

25. Choudhury J. A study on thyroid function test in children with nephrotic syndrome. Int J ContempPediatr. 2016;3:752-754.

26. Kano K, Ito S, Ichimura T. Effect of prednisolone on thyroid function in children with nephrotic syndrome. HormMetab Res 1994;26(8):395-396. 